\title{
Four species of digeneans, including Allocreadium patagonicum sp. n. (Allocreadiidae), from freshwater fishes of Patagonia, Argentina
}

\author{
Takeshi Shimazu ${ }^{1}$, Shigehiko Urawa ${ }^{2}$ and Claudio O. Coria ${ }^{3}$ \\ ${ }^{1}$ Nagano Prefectural College, 8-49-7 Miwa, Nagano 380-8525, Japan; \\ ${ }^{2}$ National Salmon Resources Center, Fisheries Agency of Japan, 2-2 Nakanoshima, Toyohira-ku, Sapporo 062-0922, Japan; \\ ${ }^{3}$ Centro de Ecología Aplicada del Neuquén, CC 7, 8371 Junín de los Andes, Neuquén, Argentina
}

Key words: Digenea, Allocreadium patagonicum, freshwater fishes, Patagonia, Argentina

\begin{abstract}
Four species of adult digeneans are reported from freshwater fishes of two lakes in Neuquén, Patagonia, Argentina. Allocreadium patagonicum sp. n. (Allocreadiidae) is described from the intestine of Percichthys colhuapiensis MacDonagh and Percichthys trucha (Cuvier et Valenciennes) (Percichthyidae) from Lago Aluminé. Three species redescribed are: Acanthostomoides apophalliformis Szidat, 1956 (Acanthostomidae) from the intestine of $P$. colhuapiensis and $P$. trucha from Lago Aluminé and of Salmo trutta (Linnaeus) (Salmonidae) from Lago Huechulafquén; Deropegus patagonicus (Szidat, 1956) comb. n. (= Genarches patagonicus Szidat, 1956) (Derogenidae) from the stomach of P. colhuapiensis, P. trucha, Oncorhynchus mykiss (Walbaum) (Salmonidae) and Salvelinus fontinalis (Mitchill) (Salmonidae) from Lago Aluminé and of $S$. trutta from Lago Huechulafquén; and Austrocreadium papilliferum Szidat, 1956 from the intestine of $P$. trucha from Lago Aluminé. The genus Polylekithum Arnold, 1934 is considered a synonym of the genus Allocreadium Looss, 1900. The genus Austrocreadium Szidat, 1956 is removed to the family Homalometridae.
\end{abstract}

Szidat (1956) described three new species of digeneans, Acanthostomoides apophalliformis, Austrocreadium papilliferum and Genarches patagonicus, from freshwater fishes of Patagonia, Argentina. Their morphology has not been studied further since then. In this paper, they are redescribed with discussion on their taxonomic positions and another new species is added on the basis of material obtained from freshwater fishes of Neuquén, Patagonia, in late 1992.

\section{MATERIALS AND METHODS}

Freshwater fishes caught in two lakes, Lago Aluminé and Lago Huechulafquén, of the Río Rimay system in Neuquén, Patagonia, Argentina, were examined for parasites (see Moravec et al. 1997). They included: Salmo trutta (Linnaeus) (Salmonidae) $(\mathrm{n}=6)$ from Lago Huechulafquén on 25 November 1992; and Percichthys colhuapiensis MacDonagh $(\mathrm{n}=2)$, Percichthys trucha (Cuvier et Valenciennes) (Percichthyidae) $(\mathrm{n}=13)$, Oncorhynchus mykiss (Walbaum) $(\mathrm{n}=10)$ and Salvelinus fontinalis (Mitchill) (Salmonidae) $(\mathrm{n}=$ 4) from Lago Aluminé on 1 December 1992. No data were recorded on the prevalence and intensity of infection of each parasite species in each host fish species from each locality.

Adult flukes obtained were flattened, fixed in $70 \%$ ethanol, stained with alum carmine and mounted in Canada balsam. Drawings were made with the aid of a drawing tube. Measurements are given in millimetres unless otherwise stated. The type and voucher specimens have been deposited in the National Science Museum, Tokyo (NSMT); and in the Institute of Parasitology, Academy of Sciences of the Czech Republic, České Budějovice, Czech Republic (IPCAS).

\section{RESULTS}

Family: A c a n t h o s t o m id a e

Acanthostomoides apophalliformis Szidat, 1956

Figs. 1-4

A total of 1 immature and 19 gravid specimens (NSMT-Pl 4579-4582 and IPCAS D-422) of this species were found in the intestine of $S$. trutta from Lago Huechulafquén on 25 November 1992 and of $P$. colhuapiensis and $P$. trucha from Lago Aluminé on 1 December 1992. Five better gravid specimens were measured. The remaining 14 gravid ones had the forebody extended enormously.

Redescription. Body lanceolate, 2.80-3.50 long by 0.60-0.70 wide (Fig. 1). Tegumental spines large and dense in forebody, becoming smaller and sparser towards posterior end of body. Eyespot pigment scattered in forebody. Brown body pigmentation light. Oral sucker almost terminal, funnel-shaped, 0.15-0.24 long by 0.27-0.32 wide; oral spines all similar in shape and size, arranged in 2 crowns of 26 each, 40-42 $\mu \mathrm{m}$ long, 26-30 $\mu \mathrm{m}$ wide at base. Prepharynx present, 0.06-0.12 long. Pharynx elliptical, $0.08-0.12$ long by $0.07-0.08$ wide. Oesophagus long, 0.21-0.36 long, bifurcating into caeca about halfway between two suckers. Caeca terminating blindly near posterior end of body. Ventral sucker lying in a hollow of ventral body wall (Figs. 1, 2), slightly posterior to junction of anterior and middle thirds of body, 0.19-0.26 long by 0.23-0.26 wide; sucker width ratio $1: 0.8$. Testes almost globular, diagonal, almost contiguous in third quarter of hindbody; anterior testis 
0.28-0.43 long by $0.31-0.39$ wide; posterior $0.36-0.51$ long by $0.31-0.41$. Cirrus pouch absent. Seminal vesicle long, bipartite, free in parenchyma between ventral sucker and ovary. Pars prostatica globular, surrounded by numerous prostatic cells free in parenchyma. Ejaculatory duct long (Fig. 2). Genital atrium distinct, extensible. Genital pore median, opening beside anterior wall of ventral sucker (Fig. 2). No gonotyl seen in hollow. Ovary spherical, almost median between seminal vesicle and anterior testis, 0.24-0.27 long by 0.32-0.37 wide. Seminal receptacle canalicular, fusiform, on postero-medial side of ovary; Laurer's canal long, originating from distal end of seminal receptacle, running backwards to open dorsally at level of anterior testis (Fig. 3). Ootype-complex lateral to ovary. Uterus coiled preovarian; metraterm weakly developed. Uterine eggs numerous, operculate, not embryonated, $36-44$ by $22-26 \mu \mathrm{m}$; an irregular hexagonal pattern present on eggshell (Fig. 4). Vitelline follicles distributed dense from level of ovary to posterior end of body, present ventral and dorsal to caeca, confluent in post-testicular region. Excretory vesicle Y-shaped, reaching to ovary, with very short arms; excretory pore terminal, surrounded by gland cells.

Remarks. Szidat (1956) described this species as a new genus and species from the intestine of $P$. trucha from the Río Limay, Río Negro. The present specimens agree in general morphology and measurements with Szidat's original description. Morphological details to be mentioned are: (1) the oral spines number 26 in each crown instead of about 30 (Szidat op. cit.); (2) a bipartite seminal vesicle is well developed and large instead of very weakly developed (Szidat op. cit.); (3) a globular pars prostatica is surrounded by numerous prostatic cells free in the parenchyma; (4) the ovary is slightly smaller than the testes instead of twice as large as them (Szidat op. cit.); (5) a canalicular seminal receptacle is present; (6) no gonotyl is observed in the hollow of the ventral body wall; and (7) an irregular hexagonal pattern is present on the eggshell.

Szidat (op. cit.) originally allocated the genus Acanthostomoides to the subfamily Cryptogoniminae in the family Heterophyidae. Yamaguti (1971) proposed a new subfamily, Acanthostomoidinae, for it in the family Acanthostomidae. It is uncertain at present whether the peculiar hollow of the ventral body wall is homologous with the ventrogenital sac in the family Heterophyidae.

\section{Family: A 11 o c re a d i i d a e}

\section{Allocreadium patagonicum sp. $\mathrm{n}$.}

Figs. 5-7

A total of 20 gravid specimens of this species were found in the intestine of $P$. colhuapiensis and $P$. trucha from Lago Aluminé on 1 December 1992. Measurements were taken of 10 gravid specimens including the holotype (those of the holotype in parentheses).
Description. Body elongate, 2.00-2.54 (2.54) long by $0.58-0.70$ (0.70) wide (Fig. 5). Tegument smooth. Eyespot pigment solid or dispersed in forebody. Oral sucker subterminal, $0.32-0.36(0.36)$ long by $0.31-0.33$ (0.33) wide; mouth triangular. Prepharynx absent. Pharynx elliptical, 0.09-0.10 (0.10) long by 0.08-0.12 (0.11) wide. Oesophagus long, S-shaped, measuring 0.17 long in an extended specimen, bifurcating into caeca halfway between pharynx and ventral sucker or dorsally to cirrus pouch (Figs. 5, 6). Caeca terminating blindly some distance from posterior end of body. Ventral sucker located at about junction of anterior and middle thirds of body, 0.25-0.31 (0.29) long by 0.25 0.37 (0.35) wide; sucker width ratio $1: 1.00-1.10$ (1.04). Testes globular to elliptical, tandem, contiguous, in middle third of hindbody; anterior testis $0.26-0.39$ (0.37) long by $0.29-0.34(0.33)$ wide; posterior 0.33 0.39 (0.39) long by $0.27-0.33(0.33)$. Cirrus pouch clavate, anteriorly curved ventral, lying diagonally in front of ventral sucker, $0.33-0.37$ (0.35) long by 0.16 0.17 (0.16) wide (Fig. 6). Seminal vesicle long, coiled once. Pars prostatica elliptical, accompanied by numerous prostatic cells. Ejaculatory duct (or cirrus) long, convoluted. Genital atrium small. Genital pore almost median, bifurcal. Ovary nearly triangular, located postero-sinistral to ventral sucker, 0.16-0.25 (0.25) long by $0.14-0.19 \quad(0.17)$ wide. Seminal receptacle retort-shaped, dilated and curved anteriorly, $0.19-0.25$ (0.22) long by $0.10-0.16(0.12)$ wide (Fig. 7). Laurer's canal running backwards to open dorsally in front of anterior testis. Ootype-complex obscure owing to uterine eggs. Uterus folded pre-testicular, sometimes extending on both sides of anterior testis to its posterior border. Uterine eggs numerous, operculate, not embryonated, 68-80 (68-76) by 40-54 (40-54) $\mu \mathrm{m}$ (collapsed). Vitelline follicles dense, distributed between oral sucker and posterior end of body, close but separate in forebody, present ventral and dorsal to caeca, confluent dorsally in post-testicular region. Excretory vesicle I-shaped, reaching ovary; excretory pore terminal, surrounded by gland cells.

Remarks. The vitelline follicles extend anteriorly into the forebody in this species, as described above. This is one of the generic characters of an allocreadiid genus, Polylekithum Arnold, 1934, as defined by Arnold (1934). This genus differs from a closely related genus, Allocreadium Looss, 1900, only in that the anterior limit of the lateral vitelline fields is present in the forebody. The use of this feature as a generic criterion is very inconsistent, being generally not accepted, for example, in another allocreadiid genus Crepidostomum Braun, 1900 (Gibson 1996). Several species with such the anterior limit of the vitelline fields have been actually described in the genus Allocreadium (see Koval' 1966). It is considered that the genera Allocreadium and Polylekithum are synonymous. 

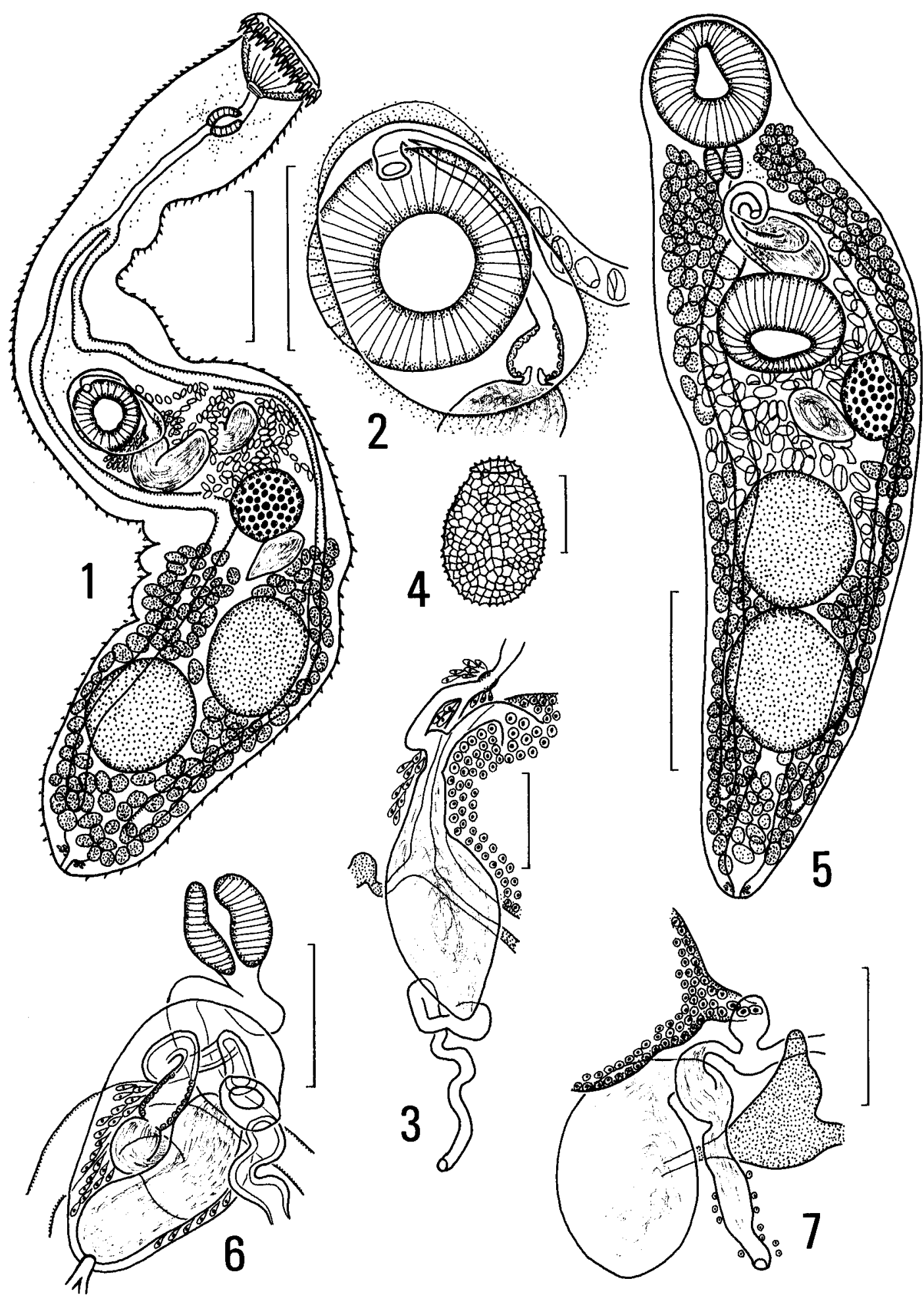
Morphologically, this new species, Allocreadium patagonicum, seems most closely similar to $A$. pseudotritoni Rankin, 1937 as described by Rankin (1937) from salamanders of North America; but it is different from the latter in having the oesophagus being long and S-shaped instead of short and straight, the cirrus pouch and genital pore being bifurcal instead of post-bifurcal, the testes being entire instead of somewhat lobate, and an I-shaped instead of a sacculate excretory vesicle reaching the ovary. The new species is distinguished from $A$. ictaluri Pearse, $1924[=P$. ictaluri (Pearse, 1924) Arnold, 1934; A. halli Mueller et Van Cleave, 1932; P. halli (Mueller et Van Cleave, 1932) Arnold, 1934] as described by Pearse (1924), Mueller and Van Cleave (1932) and Arnold (1934) from freshwater fishes of North America by having the vitelline follicles extending to the oral sucker instead of to the pharynx and being close but separate in the forebody instead of confluent there, the oesophagus being long and S-shaped instead of short and straight, the ventral sucker being shortly post-bifurcal instead of far post-bifurcal, the cirrus pouch and genital pore being bifurcal instead of far post-bifurcal, and smaller eggs (68-80 by $40-54 \mu \mathrm{m}$ instead of $87-99$ by $59-70$ $\mu \mathrm{m})$. Similarly, the new species is separated also from A. catlai Kakaji, 1969 [= P. catlai (Kakaji, 1969) Yamaguti, 1971] as described by Kakaji (1969) from a freshwater fish of India. The new species resembles $A$. kamalai Gupta, 1956 as described by Gupta (1956) from a freshwater fish of India in having the vitelline follicles extending to the oral sucker; but it differs from the latter in having the oesophagus being long and Sshaped instead of short and straight, the ventral sucker being almost as large as instead of much larger than the oral sucker, a larger cirrus pouch, denser vitelline follicles, and larger eggs ( $68-80$ by $40-54 \mu \mathrm{m}$ instead of 0.04-0.07 by 0.04-0.06 mm). P. fangosi Naveira Cortizas et Nasir, 1973 from a marine fish of South America is regarded as a nomen nudum because it was insuf-ficiently described in an abstract with no figure (Naveira Cortizas and Nasir 1973).

H o s t s : Percichthys colhuapiensis MacDonagh (type host) and $P$. trucha (Cuvier et Valenciennes) (Percichthyidae).

Site of in fection: Intestine.

T y p e 1 o c a 1 i t y : Lago Aluminé, Neuquén, Patagonia, Argentina.

$\mathrm{T}$ y $\mathrm{p}$ e $\mathrm{s} \mathrm{p}$ e c i m e $\mathrm{n} \mathrm{s}$ : Holotype and nine paratypes (NSMT-Pl 4583) and ten paratypes (IPCAS D-424).

E t y $\mathrm{m}$ o $l$ o g y : The species is named after its type locality in Argentina.

Family: D e r o g e n i d a e

Deropegus patagonicus (Szidat, 1956) comb. n.

Figs. 8-10

A total of 2 almost mature and 68 gravid specimens (NSMT-P1 4584-4587 and IPCAS D-423) were found in the stomach of $S$. trutta from Lago Huechulafquén on
25 November 1992; and of O. mykiss, P. colhuapiensis, $P$. trucha and $S$. fontinalis from Lago Aluminé on 1 December 1992. Ten larger gravid specimens were measured.

Redescription. Body oval, 1.34-1.80 long by 0.60 0.72 wide (Fig. 8). Tegument smooth. Preoral lobe surmounting oral sucker. Oral sucker subterminal, 0.140.18 long by $0.18-0.23$ wide. Prepharynx absent. Pharynx globular, 0.08-0.09 in diameter. Oesophagus small, thick-walled, accompanied by numerous small gland cells, with a valve-like process at dorsal common entrance into globular ciliated glandular stomachs (Figs. $8,9)$. Caeca undulating, terminating blindly near level of ovary. Ventral sucker large, located slightly anterior to mid-level of body, $0.39-0.46$ long by $0.39-0.48$ wide; sucker width ratio $1: 2.0-2.2$. Testes elliptical, slightly oblique, lateral at mid-level of hindbody, 0.19-0.25 long by $0.13-0.19$ wide. Seminal vesicle consisting of posterior elliptical and anterior tubular parts, not constricted between them, free in parenchyma. Pars prostatica tubular; prostatic cells free in parenchyma, composed of ones with cytoplasmic granules stained with carmine and others without them. Ejaculatory duct short, entering base of a hemispherical sinus sac to join uterus to form a hermaphroditic duct running in sinus organ to open at its anterior tip; sinus organ permanent, muscular, cone-shaped, 0.06-0.07 long, in a large bellshaped genital atrium. Genital pore almost median, at level of pharynx. Ovary elliptical, usually between left testis and left vitellarium, $0.13-0.16$ long by $0.12-0.16$ wide. Laurer's canal running forwards along median line to open dorsally at level of anterior margin of ovary, slightly dilated proximally to store sperm (Fig. 10). Juel's organ absent. Ootype-complex median; Mehlis' gland compact, lacking a sheath. Uterus coiled in all available intercaecal space between prostatic complex and vitellarium, with a small part extending into post-vitelline region in larger specimens; uterine seminal receptacle present; metraterm not developed. Uterine eggs numerous, operculate, fully embryonated when laid, $38-50$ by $22-24 \mu \mathrm{m}$, with no polar filaments. Vitellarium consisting of 2 compact masses, elliptical, near posterior end of body, 0.14-0.20 long by 0.09-0.16, sometimes with slight 1-3 incisions. Excretory vesicle Y-shaped, with arms fused dorsal to oral sucker; excretory pore terminal.

Remarks. Szidat (1956) described this species as a new species, Genarches patagonicus, in the subfamily Derogenetinae [sic] in the family Hemiuridae from the stomach of $P$. trucha from Lago Pellegrini and the Río Limay, Río Negro. The present specimens agree in general morphology and measurements with Szidat's original description. However, the study of them supplements the following morphological details to it: (1) a small oesophagus is present; (2) a valve-like process is present at the dorsal common entrance from 

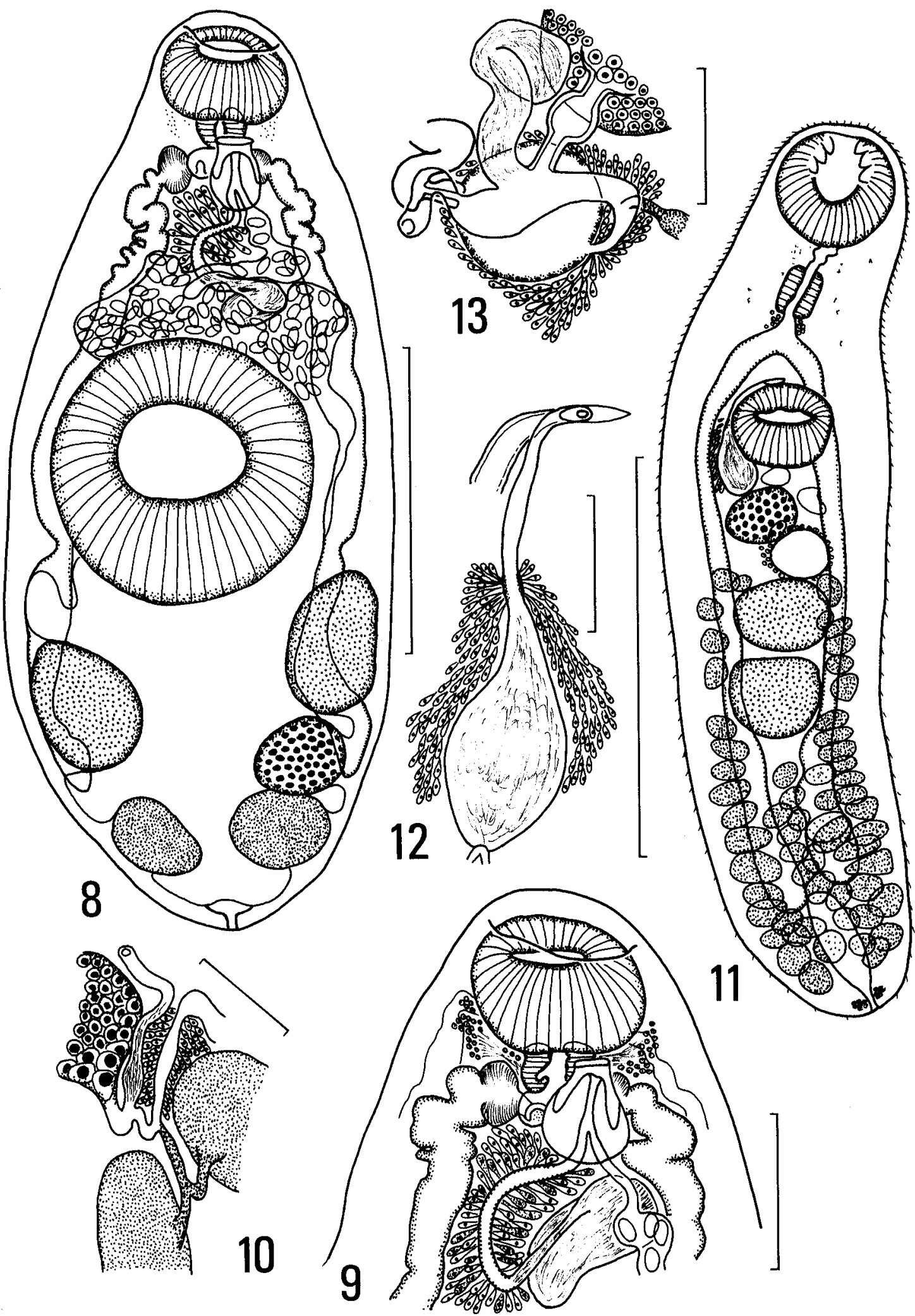

Figs. 8-10. Deropegus patagonicus (Szidat, 1956). Fig. 8. Entire worm, eggs in posterior two-thirds of uterus omitted, ventral view. Fig. 9. Anterior part of body, ventral view. Fig. 10. Ovarian complex, dorsal view. Figs. 11-13. Austrocreadium papilliferum Szidat, 1956. Fig. 11. Entire worm, ventral view. Fig. 12. Terminal genitalia, ventral view. Fig. 13. Ovarian complex, dorsal view. Scale bars: Figs. 8, $11=0.5 \mathrm{~mm}$; Fig. $9=0.2 \mathrm{~mm}$; Figs. 10, 12, $13=0.1 \mathrm{~mm}$. 
the oesophagus into the stomachs; (3) globular ciliated glandular stomachs are present; (4) a tubular pars prostatica is surrounded by numerous prostatic cells, which consist of two types according to the presence or absence of the basophilic cytoplasmic granules stained with carmine; (5) a permanent sinus organ is well developed in a large genital atrium; (6) Laurer's canal is present, opening dorsally; (7) the greater part of the uterus is coiled anterior to the vitellarium, with only a small part in the post-vitelline region in larger specimens; and (8) uterine eggs are $38-50$ by $22-24 \mu \mathrm{m}$. Szidat (op. cit.) gave the egg measurement as 0.039-0.4 $\mathrm{mm}$ long by $0.02 \mathrm{~mm}$ wide, which however should be erroneous.

Yamaguti (1971) transferred G. patagonicus to the genus Derogenes Lühe, 1900 as D. patagonicus in the subfamily Derogeninae in the family Hemiuridae. However, the above-mentioned characteristics of the species fit those of the genus Deropegus McCauley et Pratt, 1961 (= Parahalipegus Wootton et Powell, 1964, preoccupied) as defined by McCauley and Pratt (1961) in the subfamily Halipeginae in the family Hemiuridae. Therefore, the species should be removed to the genus as Deropegus patagonicus (Szidat, 1956) comb. n. It differs from D. aspina (Ingles, 1936) McCauley et Pratt, 1961 [= Halipegus aspina Ingles, 1936; P. aspina (Ingles, 1936) Wootton et Powell, 1964], the type and only species of the genus, as described by Ingles (1936), McCauley and Pratt (1961) and Wootton and Powell (1964) from a frog and freshwater fishes of North America in having (1) the caeca ending at about the ovarian level instead of at the posterior end of the body, (2) the pars prostatica being tubular instead of globular, (3) the ovary being just post-testicular instead of separated from the testis by uterine folds, (4) the greater part of the uterus being coiled between the prostatic complex and vitellarium instead of between the ventral sucker and ovary, and (5) the genital pore being at the pharyngeal level instead of post-bifurcal. Gibson and Bray (1979) recognise the genus in the subfamily Halipeginae in the family Derogenidae.

Family: H o m a 1 o m e $\mathrm{tr}$ i d a e

\section{Austrocreadium papilliferum Szidat, 1956}

Figs. 11-13

A total of nine almost mature and two gravid specimens (NSMT-Pl 4582) were found in the intestine of P. trucha from Lago Aluminé on 1 December 1992. Ten specimens were measured.

Redescription. Body elongate-linguiform, 2.20-2.60 long by $0.56-0.60$ wide (Fig. 11). Tegumental spines small, dense in forebody, becoming sparser towards posterior end of body. Eyespot pigment diffuse in forebody. Oral sucker subterminal, 0.27-0.28 long by $0.24-0.28$ wide, with a small notch at its antero-ventral part; 3 papillae arranged longitudinally on anterior half of oral sucker at each side of mouth. Prepharynx 0.060.16 long. Pharynx elliptical, 0.12-0.14 long by 0.09 0.10 wide. Oesophagus very short, surrounded by gland cells, bifurcating into caeca about halfway between two suckers. Caeca terminating blindly some distance from posterior end of body. Ventral sucker located slightly posterior to junction of anterior and middle thirds of body, 0.19-0.20 long by 0.23-0.24 wide; sucker width ratio $1: 0.8-0.9$. Testes spherical or elliptical, tandem, contiguous, slightly posterior to mid-level of body, $0.16-0.26$ long by $0.15-0.23$ wide. Cirrus pouch absent (Fig. 12). Seminal vesicle pyriform, submedian, preovarian. Pars prostatica small, accompanied by numerous prostatic cells; ejaculatory duct long, joining to uterus to form a very short hermaphroditic duct. Genital pore like a transverse slit, median, just in front of ventral sucker. Ovary elliptical, submedian, pretesticular, 0.12-0.15 long by 0.11-0.15 wide, with a well-developed oocapt (Fig. 13). Seminal receptacle retort-shaped, dorsal or postero-dorsal to ovary. Laurer's canal short, submedian. Ootype large, round, postero-lateral to ovary, surrounded by Mehlis' gland; Mehlis' gland possibly opening into distal end of common oviduct. Uterus short, pre-ovarian, sinuous, with a well-developed valve and sphincter. Uterine eggs few, operculate, not embryonated, $80-92$ by $46-74 \mu \mathrm{m}$ (collapsed). Vitelline follicles large, not numerous, distributed between level of anterior border of anterior testis and posterior end of body, confluent in posttesticular region. Excretory vesicle I-shaped, short, reaching to level of caecal ends; excretory pore terminal, surrounded by gland cells.

Remarks. Szidat (1956) described this species as a new genus and species from the small intestine [sic] of P. trucha from Lago Pellegrini and the Río Limay near Plottier, Río Negro. The present specimens agree in general morphology and measurements with Szidat's description. However, the following morphological details are pointed out: (1) the tegumental spines are present all over the body, though sparser in the hindbody, instead of restricted to the part anterior to the pharyngeal level (Szidat op. cit.); (2) the cirrus pouch is entirely absent instead of present (Szidat op. cit.); (3) the seminal vesicle free in the parenchyma is elliptical instead of bipartite (Szidat op. cit.); (4) the seminal receptacle is present; and (5) the ootype is large, round and surrounded by Mehlis' gland.

Szidat (op. cit.) originally allocated the genus Austrocreadium to the family Allocreadiidae. In its type and only species, $A$. papilliferum, as shown already, the body is distinctly spinose and the cirrus pouch is entirely absent. These two features exclude the genus from the family Allocreadiidae. Besides, the diffuse eyespot pigment in the forebody suggests the presence of eyespots in the cercaria of the species. In fact, Szidat (op. cit.) recorded encysted metacercariae of the species 
with two eyespots from ammocoetes of Geotria australis (Agnatha) from the Río Limay. It seems from the above that the genus should be placed in the subfamily Homalometrinae in the family Homalometridae as seen in Stunkard (1964), Yamaguti (1971) and Gibson (1996) though the hermaphroditic duct is very short in the type species.

The genus Austrocreadium is unique in having three pairs of papillae arranged longitudinally on the anterior half of the oral sucker at the sides of the mouth and a large round ootype. Out of the six genera listed by Yamaguti (op. cit.) in the subfamily, the genus Dactylotrema Bravo-Hollis et Manter, 1957 possesses six pairs of marginal processes embedded in the wall of the outer margin of the oral sucker dorsally and laterally
(Bravo-Hollis and Manter 1957); and the genus Barbulostomum Ramsey, 1965 has a pair of papillae on the ventro-lateral edge of the oral sucker on the sides of the mouth (Ramsey 1965). In addition, Homalometron elongatum Manter, 1947 bears three or four pairs of papillae on the oral sucker on the sides of the mouth (Bravo-Hollis and Manter op. cit., Ramsey op. cit.). The papillae figured by Bravo-Hollis and Manter (op. cit., fig. 12) for $H$. elongatum resemble those of the present species in number and arrangement.

Acknowledgements. We thank Drs. Mitsuo Sakai and Ariaky Nagasawa of the Japan International Cooperative Agency (JAICA); and members of the staff of Centro de Ecología Aplicada del Neuquén, for their assistance in collecting fish samples in the field.

\section{REFERENCES}

ARNOLD J.G., Jr. 1934: Some trematodes of the common bullhead Ameiurus nebulosus (Le Sueur). Trans. Am. Microsc. Soc. 53: 267-276.

BRAVO-HOLLIS M., MANTER H.W. 1957: Trematodes of marine fishes of Mexican waters. X. Thirteen Digenea, including nine new species and two new genera, from the Pacific coast. Proc. Helminthol. Soc. Wash. 24: 35-48.

GIBSON D.I. 1996: Trematoda. In: L. Margolis and Z. Kabata (Eds.), Guide to the Parasites of Fishes of Canada. Part IV. NRC Research Press, Ottawa, ix +373 pp.

GIBSON D.I., BRAY R.A. 1979: The Hemiuroidea: terminology, systematics and evolution. Bull. Br. Mus. Nat. Hist. (Zool.) 36: 35-146.

GUPTA S.P. 1956: Two new trematodes of the family Allocreadiidae from the fresh-water fishes of U. P. Indian J. Helminthol. 8: 100-106.

INGLES L.G. 1936: Worm parasites of California Amphibia. Trans. Am. Microsc. Soc. 55: 73-92.

KAKAJI V.L. 1969: Studies on helminth parasites of Indian fishes. Part III. Some trematode parasites of fresh water fishes of Uttar Pradesh. Indian J. Helminthol. 21: 49-80.

KOVAL' V.P. 1966: Family Allocreadiidae Stossich, 1903. In: K. I. Skrjabin (Ed.), Trematodes of Animals and Men. Izdatel'stvo AN SSSR, Moskva, pp. 185-310. (In Russian.)

McCAULEY J.E., PRATT I. 1961: A new genus Deropegus with a redescription of $D$. aspina (Ingles, 1936) nov. comb. Trans. Am. Microsc. Soc. 80: 373-377.

MORAVEC F., URAWA S., CORIA C.O. 1997: Philonema percichthydis sp. n. (Nematoda: Philometridae) from the Patagonian smallmouth perch Percichthys trucha (Pisces) from Argentina. Helminthologia 34: 215-219.
MUELLER J.F., VAN CLEAVE H.J. 1932: Parasites of Oneida Lake fishes. Part II. Descriptions of new species and some general taxonomic considerations, especially concerning the trematode family Heterophyidae. Roosevelt Wild Life Ann. 3: 79-137.

NAVEIRA CORTIZAS J.L., NASIR P. 1973: Polylekithum fangosi sp. n. (Trematoda: Digenea) [Allocreadiidae: Allocreadiinae], primer representante en un pez marino, Amphichthys cryptocentrus Cuvier y Valenciennes, 1837. Acta Cient. Venez. 24 (Suppl. 1): 58.

PEARSE A.S. 1924: Observations on parasitic worms from Wisconsin fishes. Trans. Wis. Acad. Sci. Arts Lett. 21: 147-160.

RAMSEY J.S. 1965: Barbulostomum cupuloris gen. et sp. n. (Trematoda: Lepocreadiidae) from sunfishes (Lepomis spp.) in Lake Pontchartrain, Louisiana. J. Parasitol. 51: 777-780.

RANKIN J.S., Jr. 1937: New helminths from North Carolina salamanders. J. Parasitol. 23: 29-42.

STUNKARD H.W. 1964: The morphology, life-history, and systematics of the digenetic trematode, Homalometron pallidum Stafford, 1904. Biol. Bull. 126: 163-173.

SZIDAT L. 1956: Über die Parasitenfauna von Percichthys trucha (Cuv. \& Val.) Girard der patagonischen Gewässer und die Beziehungen des Wirtsfisches und seiner Parasiten zur paläarktischen Region. Arch. Hydrobiol. 51: 542-577.

WOOTTON D.M., POWELL E.C. 1964: Parahalipegus (gen. n.) for Halipegus aspina Ingles, 1936 (Hemiuridae: Trematoda). J. Parasitol. 50: 662-663.

YAMAGUTI S. 1971. Synopsis of Digenetic Trematodes of Vertebrates. Keigaku Publishing Co., Tokyo, Vol. 1, 1074 pp.; Vol. 2, 349 pls.

Accepted 28 September 1999 